\title{
Corporate governance and democratic accountability: Local state-owned enterprises in Norway
}

By Jan Erling Klausen* (associate professor) and Marte Winsvold** (researcher)

* Department of Political Science, University of Oslo. P.O box 1097, Blindern, 0317 OSLO, Norway. Phone: (+47) 228551 91. Fax: (+47) 228544 11. Email: j.e.klausen@stv.uio.no

** Department of Political Science, University of Oslo. P.O box 1097, Blindern, 0317 OSLO, Norway. Phone: (+47) 930337 52. Fax: (+47) 228544 11. Email: m.s.winsvold@ stv.uio.no

\begin{abstract}
:
Transferring public service provision to state-owned enterprises (SOEs) raises concerns over accountability deficits. We argue that the governance of SOEs requires reconciliation of the accountability relations found in traditional models of public administration, and the normative structures of control and accountability developed in the world of private enterprises, commonly referred to as corporate governance. To this end, we propose a model for structuring accountability relations between SOEs and governmental owners. The model prescribes a distinction between the roles of elected representatives and top managers as 'forums' for accountability concerning the governmental owner's mission-related and nonmission-related preferences towards the SOE. The model's relevance is tested empirically using data from a study of SOEs in Norway's local government sector. The analysis indicates that accountability practices in line with the prescriptions of the model was associated with a heightened sense of control over the SOEs.
\end{abstract}

\section{Keywords:}

Democratic accountability, corporate governance, state-owned enterprises, local government, local governance 


\section{Introduction}

A prominent feature of public management reform during the last decades has been the devolution of tasks and services to semi-autonomous entities (Christensen and Lægreid 2001; Pollitt et al. 2001; Pollitt and Talbot 2004; Verhoest et al. 2012). Moving public services 'further out' from political control (Pollitt 2004) actualises a potential trade-off between control and autonomy (Christensen and Lægreid 2006; Bovens et al. 2008) and raises concerns over accountability deficits - a deficiency of political control by elected representatives (Mulgan 2014). A substantial body of literature has explored accountability issues related to statutory bodies, which are agencies with high degrees of autonomy but clear linkages to a parent ministry (Pollitt et al. 2001; Verhoest et al. 2010). However, these agencies constitute the penultimate case of devolution at best. More severe accountability deficits would logically be assumed in cases where public tasks are divested to even more autonomous bodies, such as state-owned enterprises (SOEs). Transferring public service provision and task fulfilment to a SOE entails a profound departure from traditional modes of public sector control and accountability. However, the implications of this shift in accountability are poorly understood. While there is a long-standing debate on the transition from public administration to public management and the general implications of this shift for accountability (Painter 1988; Hughes 1992), only recently has a growing awareness of the specific accountability problems associated with SOEs been evident (Luke 2010; Bruton et al. 2015; Grossi et al. 2015; Olsen et al. 2017). Following the pervasive «corporatisation» of the public sector in many countries, increasing attention to market signals and corporate strategy may divert attention away from the political agendas of elected principals. But as noted by Caiden (1994), "all public administration is political: it is an instrument of politics and political values dominate". To the extent that policy-makers persist in using SOEs as 
instruments for achieving politically decided goals, improved understanding of the preconditions for democratic control and accountability is clearly needed.

We argue that the specific accountability problems associated with SOEs can only be understood properly by examining how the challenge of ensuring control and accountability has been met in the world of private enterprise. The private-sector approach to accountability is commonly referred to as corporate governance (Berle and Means 1933; Blair 1995; Hart 1995), a rather elusive and multidimensional term. From a legal standpoint, corporate governance refers to structures and procedures laid down by corporate law, such as governing bodies and the distribution of roles and authority between them. From an analytical perspective, corporate governance relates to a growing body of work aspiring to create a global corporate governance theory ${ }^{1}$. Corporate governance is clearly a normative system, epitomised notably by the G20/OECD Principles of Corporate Governance (OECD 2015a) ${ }^{2}$. In the present context, we conceptualise corporate governance as a system of accountability relations (Bovens et al. 2008). As such, we contrast corporate governance with the accountability relations found in traditional models of public administration. We argue that accountable governance of SOEs requires reconciliation of the disparities between these two systems of accountability relations.

To this end, we propose a model for structuring accountability relations between SOEs and governmental owners based on the distinction between political and managerial accountability. A key aspect to the model is that democratic control requires SOE managers to be accountable to elected politicians for issues pertaining to goal definition and goal obtainment. In order to safeguard managerial autonomy, however, the responsibility for overseeing SOEs in matters related to running operations should primarily reside with top managers. This model's relevance is tested empirically, based on data from our study of SOEs in Norway's local government sector (Bjørnsen et al. 2015). ${ }^{3}$ We examine how 
political and managerial accountability relations play out through the different 'phases' of account giving. Our key hypothesis is that account giving, structured in accordance with the model we propose, is associated with positive evaluations of overall accountability and control.

\section{Public versus private sector accountability}

Accountability, in a literal sense, means being called 'to account' to some authority for one's actions (Jones 1992). As has been noted, although accountability is a contested and widely used concept, many authors agree to a considerable extent about the term's defining features (Brandsma and Schillemans 2013). In what follows, we choose to take as a point of departure Bovens' (2007) commonly cited 'narrow' definition of accountability as 'a relationship between an actor and a forum, in which the actor has an obligation to explain and to justify his or her conduct, the forum can pose questions and pass judgment, and the actor may face consequences' (p. 450) ${ }^{4}$. This definition has been reformulated by Schillemans (2011) as three 'phases' of account giving: In the information phase, the actor provides information about his or her conduct; in the discussion phase, the forum may ask questions and the actor is obliged to answer; and in the consequence phase, the forum may pass a judgement and make the actor face consequences.

Established conceptions of representative democracy and public administration, such as the parliamentarian system of government, rely on a comprehensive chain of accountability relations (Hughes 1992; Fuller and Roffey 1993; Parker and Gould 1999). Bureaucrats on all levels, from street-level service providers and up, are accountable to their superiors, and top public managers are accountable to ministers (Barberis 1998; Hodge and Coghill 2007; Mulgan 2014). In turn, ministers are accountable to parliament, and finally, parliament is 
accountable to the people. We will refer to the representative system of control and accountability as the 'integrated' model, since democratic accountability relies on an unbroken chain of accountability relations between hierarchically ordered agents and forums. ${ }^{5}$ In each relation, the agent is obliged to provide information and clarification about his or her conduct. The forum can ask questions, pass judgment and make the agent face the consequences of his or her behaviour (Bovens 2007).

In the literature on public sector accountability, the integrated model of democratic accountability has been problematized from several angles. Johnson (1982) warned that, in practice, the controlling effect of ministerial accountability is often extremely limited. At the extreme end of the spectrum, critics have depicted ministerial accountability as a 'system for the mutually-reinforcing active concealment of government action and public purposes' (Lewis and Longley 1996). Barberis (1998) contended that the traditional accountability doctrine always 'lived on a wing and a prayer', partially due to elements of ambiguity and confusion surrounding the concept. Notably, erosion of ministerial responsibility occurs when senior officials, instead of the responsible minister, are called to account for decisions that have gone awry. Even so, ministerial accountability and the integrated model overall remain the cornerstones of public sector accountability.

A paradigmatic change in the conceptualisation of public sector accountability came with the transition from the traditional model of public administration to new models of public “management" (Allison 1982; Painter 1988; Gray and Jenkins 1995). A key distinction is that public management not only involves carrying out policies decided by others; it also involves "organisation to achieve objectives with maximum efficiency, as well as genuine responsibility for results" (Hughes 1992). Bureaucrats consequently attain a role more similar to that of top managers in private enterprises. In what follows we focus on the implications for democratic accountability of the transition from public administration to public 
management, and specifically the introduction of corporate governance to the public sector. We conceive of corporate governance as the private-sector counterpart of the integrated model of public-sector control and accountability. Corporate governance has been portrayed as a system of checks and balances on managerial behaviour, a system for delimiting the managers' ability to pursue their personal agendas (Blair 1995; Hart 1995). The need for such checks and balances stems from the dispersion of listed companies' ownership between large numbers of small owners. Shareholders are often too small and numerous to exercise control on a day-to-day basis, and individually, they have little or no incentive to monitor management (Hart 1995). Thus, dispersed ownership necessitates a separation between ownership and control (Berle and Means 1933), or in other words, delegation of authority to the company's management. Hence, to some extent, delegation of authority is a practical necessity. At the same time, providing managers with discretionary powers is a strategy for maximising returns. These twin purposes of practical necessity and revenue maximisation were elucidated by the OECD (2015a), as follows:

As a practical matter $(\ldots)$ the corporation cannot be managed by shareholder referendum. (...) The corporation's management must be able to take business decisions rapidly. In light of these realities and the complexity of managing the corporation's affairs in fast moving and ever changing markets, shareholders are not expected to assume responsibility for managing corporate activities. The responsibility for corporate strategy and operations is typically placed in the hands of the board and a management team that is selected, motivated and, when necessary, replaced by the board. (p. 18)

Following this, a key aspect of corporate governance is avoiding undue interference from the owners in day-to-day management decisions. Managerial autonomy may however give rise to agency problems. The owners of the enterprise have reasons to fear that the manager will 
promote a personal agenda, for instance, by seeking extravagant perks. A key institutional mechanism to counter such pathologies is the introduction of a governing body that acts on the owner's behalf to oversee and provide directions to management. This system is depicted by the simplified model of corporate governance provided by Tricker (1995), who defined corporate governance as the 'formal and informal relationships, networks and structures' between five classes of actors, namely members, the governing body, management, auditors and regulators and other stakeholders.

Figure 1: Model of Corporate Governance. Adopted from Tricker (1995).

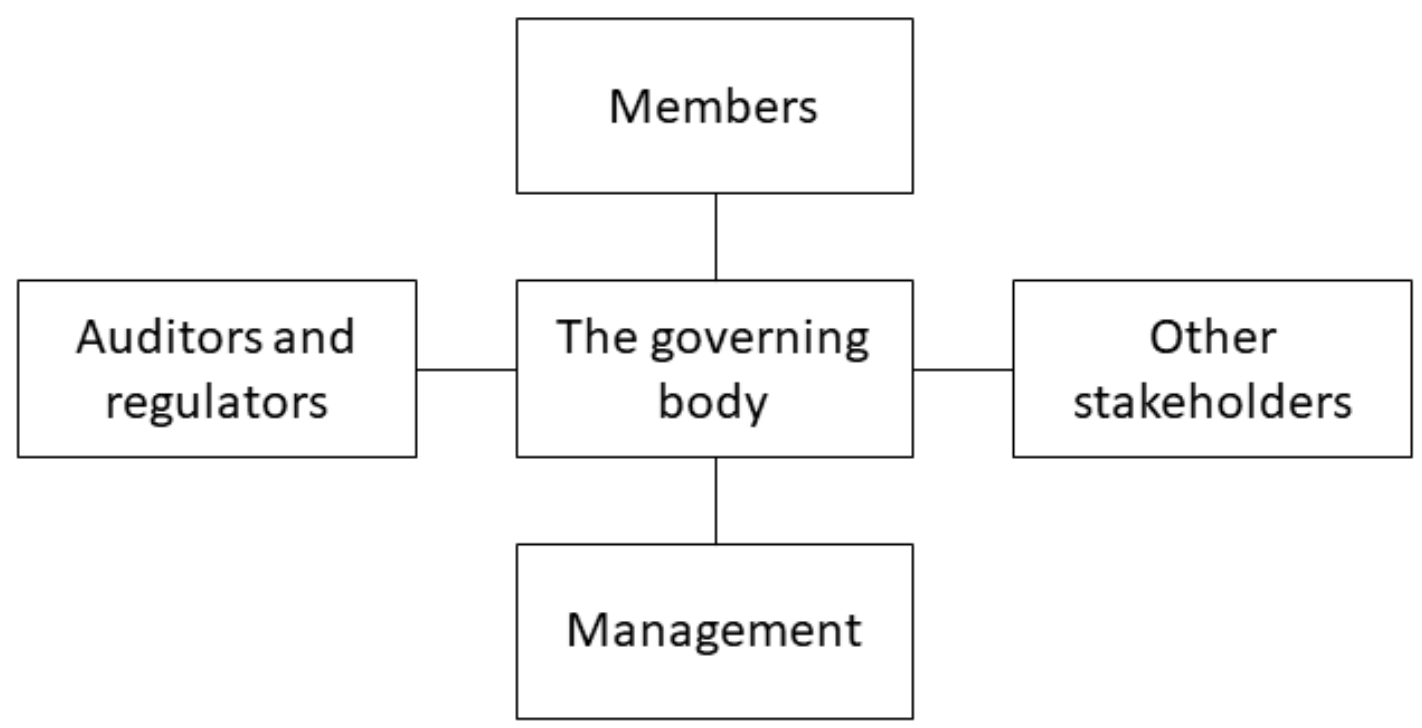

Management (the chief executive officer, CEO) is accountable to the governing body (the board), which is in turn accountable to the 'members' (owners). In this way, corporate governance enables maximization of returns by allowing management to make quick decisions to adapt to rapidly changing markets, while at the same time, keeping tabs on 
management to prevent and correct agency problems ${ }^{6}$. Thus, in principle, a working balance between autonomy and control is achievable, even in enterprises with many small owners.

Unlike many listed enterprises, SOEs often have one or a few large owners. As noted by Hart (1995), unified ownership creates an entirely different situation in terms of generating leeway for direct control by the owners, as compared with dispersed ownership: If a company has one $100 \%$ shareholder, there is no longer a separation between ownership and control. Indeed, this scenario has traditionally been typical of SOEs. Historically, public ownership, especially of monopolies for the provision of goods like electricity, telecommunications and railways, entailed extensive direct governmental intervention in running operations (Thynne 2011). The idea that SOE managers should be protected against intervention from their owners is relatively recent, and it can largely be traced back to the advent of New Public Management (NPM); (Hood 1991; Kettl 1997). A transition from 'ownership as regulation' to 'ownership and regulation' (Thynne 2011) took place as large government monopolies were dissolved, from the 1980s and onward. Institutional separation of regulatory functions from ownership of enterprises was a prerequisite for ensuring a level field of competition between public and private providers. Furthermore, scaling back direct state intervention in the SOE's running affairs was in line with the much-cited slogan 'Let the managers manage' - a key tenet of NPM (Aucoin 1990; Kettl 1997). The intention was to increase efficiency by insulating operational decisions from political interference (Bognetti and Obermann 2012; Zatti 2012).

The institutional setup of SOEs includes many features that serve to insulate operational decisions from considerations other than business-related ones. As Mulgan (1997) noted, the rationale for contracting out - efficiency gains - can largely be attributed to the ways in which reduced accountability allows greater flexibility and innovativeness in day-to-day operations, for instance, in terms of more flexible employment procedures and a reduced risk 
of being blamed for mistakes, as compared with public sector blame-gameism (Hood 2002, 2011). Perhaps unsurprisingly, the overall impression from extant research is that the balance between management autonomy and 'political interference' tends to tip in favour of the former. In his study of 'hybrid' organisations in the US government, Koppell (2003) concluded that 'the political cost of quasi-government (...) is a loss of control over public policy’ (p. 164). Similarly, Christensen, Lægreid, Peters and Bouckaert (2004) noted that structural devolution means a decrease in political authority and the capacity for exercising control and less attention to political considerations in state-owned companies. In their Guidelines on Corporate Governance of State-Owned Enterprises, the OECD (2015c), warned against the 'lack of any oversight due to totally passive or distant ownership' (p. 12). The general dilemma of importing corporate governance to the public sector is clearly to ensure democratic accountability and control, while allowing managerial autonomy. In the following section, we propose a theoretical model for accountable SOE ownership that seeks to reconcile the dilemma.

\section{A model for accountable SOE ownership}

The nascent literature on accountability problems related to SOEs provides certain clues as to how the dilemma of reconciling autonomy and accountability may be resolved. Based on interviews with SOE executives in New Zealand, Luke (2010) identified a complex pattern of accountability relations with multiple stakeholders, including managerial and political principals, the public in different capacities (taxpayers, citizens, voters, customers and creditors) and professional and legal stakeholders. Overall, Luke's (2010) study found that the accountability structure surrounding SOEs 'is perhaps more coherent and extensive than many commentators either realise or acknowledge' (p. 158). Especially, Luke noted that 
'SOEs' managerial accountability to Government should be distinct from SOEs' political accountability to Government'. Although this distinction at times appeared blurred, the importance of demarcating the boundaries between managerial and political issues was emphasised (p. 157). Indeed, one of the implications for practice that emerged from Luke's (2010) study was a recommendation that 'the separation of managerial and political functions should be clearly documented and included as part of a SOE regulatory framework, so that both SOEs and Government can be held accountable for fulfilling their respective roles' (p. 158).

The distinction between political and managerial accountability was also taken up by André (2010), who underscored ${ }^{7}$ the importance of a clear mission statement as a requirement for meaningful accountability. In contrast, he also noted that 'bureaucratic controls and systems comprise the government methods for keeping GSOs ${ }^{8}$ accountable' (André 2010). Accordingly, accountability requires a distinctly political regard for the mission of the SOE and its accomplishment, as well as functional procedures for bureaucratic oversight.

Similarly, in his study of 'The Politics of Quasi-Government', Koppell (2003) emphasised the distinction between control over mission-related and non-mission-related preferences. Mission-related preferences are those that 'strike at the centre of an organization's function', utilising an organisation's core technology or competence. Non-mission-related preferences 'relate to the manner in which an agency pursues its objectives' (pp. 72-73), and are often of a procedural nature. Koppell alleged that the preconditions for achieving control over each type of preference may differ. Notably, the choice of institutional structure may affect the relative degree of control over each type of preference. Politicians may for instance choose to cede control over non-mission-related preferences in the name of efficiency if they retain control over mission-related preferences. 
Following Koppell's (2003) conclusions, the key to reconciling the democratic accountability/managerial autonomy dilemma may lie in an institutionalised separation of SOE account giving related to mission-related and non-mission-related preferences. SOEs should be accountable to the elected principals of their governmental owners in matters pertaining to goal definition and goal attainment, or in other words, mission-related preferences. In contrast, elected representatives should delegate the responsibility for overseeing SOEs in matters related to running operations (non-mission-related preferences) to top public managers. The advantages of delegating oversight of running operations to managers are manifold. An obvious practical advantage is that public managers may draw on the capacity and specialised competence of the public administration to exercise this control function. An advantage that relates more directly to the general autonomy-accountability dilemma, however, is that SOEs are not part of the governmental owner's organisation. Public managers are institutionally constrained from interfering in decisions made by the management of the SOE. Only the owners, on the general assembly, can hold the SOE to account. The implication is that the accountability relationship between the public owner and SOE on matters pertaining to non-mission-related preferences should be of an indirect nature.

With reference to the three-phase conceptualisation of accountability mentioned above (Schillemans 2011), 'information' on mission-related preferences should flow directly from the agent (SOE) to the forum (elected representatives). However, for non-mission-related preferences, top public managers should be a primary recipient of 'information', and as such, they should occupy an intermediate position between the agent and forum. Top public managers should also play a role in the 'discussion' phase in the sense that they should detect signs of malfeasance or actions that could potentially infringe on mission-related preferences, and call this to the attention of elected representatives. As for the 'consequences' phase, which may involve replacing the board or changing the SOE strategy, the elected 
representatives are the forum in all cases. Figure 2 depicts the distinction between the direct accountability relation pertaining to mission-related and non-mission-related preferences.

Figure 2: Model for Structuring Accountability on Mission-Related (1) and Non-MissionRelated (2) Preferences.

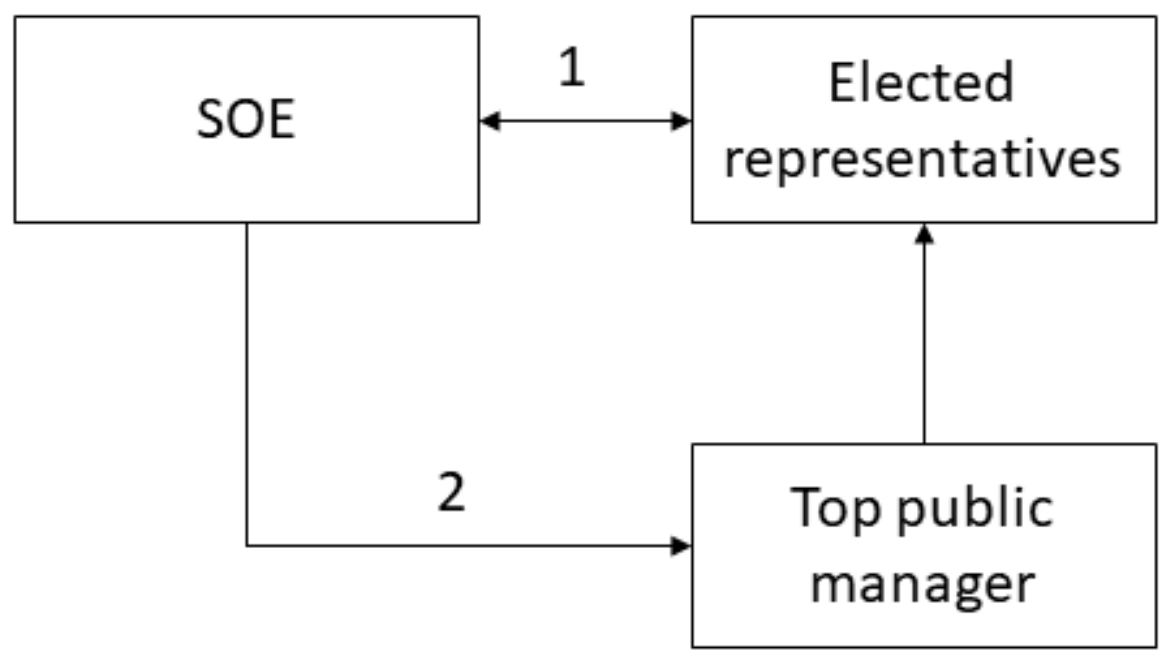

In the model in figure 2 , line 1 represents the direct accountability relationship between the SOE and elected representatives on mission-related preferences. Note that line 1 points both ways because the relationship involves both account-giving and consequences. Line 2 represents non-mission-related preferences, and it points from the SOE to the managerial level of the government owner before the information is passed on to the political level. The aim of what follows is empirically testing the relevance of this model. We adopt the following hypotheses: 
H1: Accountability and control are evaluated more positively if information about mission-related preferences (goal definition or goal obtainment) is addressed to elected representatives rather than chief managers.

$\mathrm{H} 2$ : Accountability and control are evaluated more positively if information about non-mission-related preferences (day-to-day decisions) is addressed to chief managers rather than elected representatives.

The following section presents the empirical context for the analysis.

\section{Empirical context: Local SOEs in Norway}

The empirical context of the present study is SOEs in the local government sector. SOEs have become a prominent feature of local government service provision in several European countries (Warner and Hebdon 2001; Kuhlmann 2008; Bognetti and Obermann 2012; Citroni et al. 2013; Wollmann et al. 2016). The 'demise of in-house production' (Denters and Rose 2005) and the ensuing 'corporatisation' of the local government sector (Teles 2015) has proceeded markedly, not least in Norway (Aarsæther and Vabo 2002; Gjertsen and Martiniussen 2006; Aars and Ringkjøb 2011; Bjørnsen et al. 2015). At present, almost all local governments in Norway own at least one SOE, alone or as one of several owners. The Norwegian context therefore provides a unique opportunity to investigate variations in perceived control over municipal owner interests.

In Norway, local governments are largely free to decide on their own administrative structures $^{9}$. A wide range of semi-autonomous organisational forms is available for organising municipal tasks. Because we aim at analysing how corporate governance as a private-sector accountability system works in conjunction with the 'integrated' model of public-sector accountability, our study was delimited to the two forms that correspond most 
closely to regular private enterprises: Limited liability corporations based on corporate law (Ltd) or 'intermunicipal companies' (IMCs), mandated by the Intermunicipal Companies act (Bjørnsen et al. 2015). Both the Ltd and IMC forms designate SOEs as independent legal entities. The former is used by both private and public owners, but the latter can only be owned by a group of municipalities. Unlike Ltds, IMC owners take on unlimited liability for the company's obligations. Furthermore, the ownership structure of an IMC is determined by an ownership agreement, which can only be changed by joint decision - there are no freely transferrable shares. Otherwise, the two forms are similar. The owners exert their authority in the general assembly (corporate assembly in IMCs), notably by deciding on the annual documents and appointing the company board. The CEO is chosen by, and is accountable to, the board.

At the time of study, there were 2020 SOEs held by local governments in Norway, of which 1775 were Ltds and 245 were IMCs (Bjørnsen et al. 2015). These companies belonged to a broad variety of industries. Table 1 presents these SOEs organised by branch.

Table 1: Norwegian Local State-Owned Enterprises by Branch of Industry (2014) $\%$ Percent. Source: Register of Business Enterprises/Brønnфysund Register Centre. $N=2020$

\section{Industry}

\section{Percentage}

Electricity, gas, steam and hot water supply

Real estate management 
Public administration, general

$\dagger$ Limited corporations (Ltd.) and Inter-Municipal Companies (IMC). Each Ltd or IMC may comprise one or several units.

On average, each municipality owned slightly less than seven SOEs, varying between three on average for very small municipalities (less than 5000 inhabitants) and 22 on average for large ones (more than 20000 inhabitants).

\section{Data and methods}

The data used in this study are taken from a web-based survey to all Norwegian municipalities that own at least one SOE. According to data from the Norwegian Register of 
Business Enterprises, by 2014, 407 of Norway's then 430 municipalities fell in this category. In October 2014, these 407 municipalities received an email containing a link to the survey, with the instruction to pass it on to the manager in charge of overseeing the municipality's SOEs. In smaller municipalities, this would be the chief officer (CO), whereas in larger cities, the manager in charge would be situated one or two rungs lower in the municipal hierarchy, acting on delegated powers from the $\mathrm{CO}$. We refer to the respondents as CO's, since regardless of their exact position, being responsible for overseeing the municipalities' SOEs, they act in the role of CO. Emailed reminders were distributed twice, after 2 and 4 weeks. In total, 223 municipalities out of 407 participated in the survey, resulting in a 55\% response rate. Because fifty-three respondents did not complete the survey in full, the response rate for the complete survey was $43 \%$.

Small municipalities and municipalities with few SOEs are under-represented in the net sample. $44 \%$ of municipalities below 5000 inhabitants responded, as compared to $65 \%$ of municipalities above 5000 . While $70 \%$ of municipalities owning ten SOEs or more responded, the response rate was $52 \%$ for municipalities owning fewer than ten SOEs. ${ }^{10}$ Otherwise, the municipalities in the sample are representative of Norwegian municipalities in terms of income distribution (free income per capita) and geographical spread.

Survey respondents were asked to assess the perceived level of control with ownership interest, on a 5-point Likert scale. ${ }^{11}$ The distribution on the dependent variable, displayed in Table 2, reveal substantial variation in perceived control.

Table 2. "The municipality exerts adequate control over its ownership interests".

\begin{tabular}{lll}
\hline & Percent & N \\
\hline 1 (Strongly disagree) & 9 & 16 \\
2 & 19 & 32
\end{tabular}




\begin{tabular}{lll}
3 & 32 & 55 \\
4 & 36 & 61 \\
5 (Strongly agree) & 4 & 7 \\
\hline Total & 100 & 171 \\
\hline Mean & 3.06 & \\
\hline
\end{tabular}

To test whether variation in perceived control can be attributed to accountability practices, the respondents were asked to report the use of such practices. We distinguish between accountability practices pertaining to mission-related and non-mission-related preferences, involving the elected representatives and/or the administration. We further distinguish between three phases of accountability as presented earlier: the information phase, the discussion phase, and the consequence phase (Schillemans 2011).

Accountability practices in the information phase were gauged by four items on whether or not the politicians and the administration respectively were informed of non-mission related goals (running operations) or mission-related goals (goal obtainment). As for the discussion phase, the respondents were asked whether goal and performance requirements were discussed in political forums and in the municipal administration, respectively. Whereas accountability practices in the two first phases can involve both elected representatives and the administration, passing judgment - the consequence phase - is the prerogative of the elected council. Therefore, accountability practice in the third phase was measured by one single question relating to elected representatives only: The respondents were asked to report whether the council would fire the board in case of non-compliance.

The distributions of the various accountability mechanisms are presented in table 3 .

Table 3 Independent variables. Mean values, standard deviation and skewness. N = 169 


\begin{tabular}{|c|c|c|c|c|c|c|}
\hline & & Min & Max & Mean & $\begin{array}{l}\text { Std. } \\
\text { Dev. }\end{array}$ & $\begin{array}{l}\text { Skew- } \\
\text { ness }\end{array}$ \\
\hline \multirow[t]{4}{*}{ Information $\dagger$} & $\begin{array}{l}\text { The politicians are provided } \\
\text { information about the goal } \\
\text { obtainment of the enterprise(s) }\end{array}$ & 0 & 1 & 0.47 & 0.50 & 0.11 \\
\hline & $\begin{array}{l}\text { The administration is provided } \\
\text { information about the goal } \\
\text { obtainment of the enterprise(s) }\end{array}$ & 0 & 1 & 0.60 & 0.49 & -0.43 \\
\hline & $\begin{array}{l}\text { The politicians are provided } \\
\text { information about the running } \\
\text { operations of the enterprise }(s)\end{array}$ & 0 & 1 & 0.47 & 0.50 & 0.11 \\
\hline & $\begin{array}{l}\text { The administration is provided } \\
\text { information about the running } \\
\text { operations of the enterprise }(s)\end{array}$ & 0 & 1 & 0.71 & 0.45 & -0.94 \\
\hline \multirow[t]{2}{*}{ Discussion†† } & $\begin{array}{l}\text { Enterprise goals are discussed } \\
\text { with politicians }\end{array}$ & 1 & 5 & 3.00 & 1.06 & 0.04 \\
\hline & $\begin{array}{l}\text { Enterprise goals are discussed } \\
\text { with administration }\end{array}$ & 1 & 5 & 3.50 & 1.22 & -0.48 \\
\hline Consequence $\dagger \dagger$ & $\begin{array}{l}\text { The municipality fire the board } \\
\text { leader or the board in case of } \\
\text { noncompliance. }\end{array}$ & 1 & 5 & 2.80 & 1.33 & 0.06 \\
\hline \multirow[t]{4}{*}{ Control } & $\begin{array}{l}\text { Number of administrative } \\
\text { employees }(\ln )\end{array}$ & 3.5 & 10.4 & 6.3 & 1.06 & 0.53 \\
\hline & Number of SOEs (ln) & 0 & 4.72 & 1.57 & 1.05 & 0.39 \\
\hline & Net operating result per capita & -4.4 & 43.7 & 2.45 & 4.28 & 5.99 \\
\hline & $\begin{array}{l}\text { Political fragmentation, } \\
\text { Herfindahl index }(\ln )\end{array}$ & 0.14 & 0.70 & 0.27 & 0.08 & 1.82 \\
\hline
\end{tabular}

$\dagger$ Dichotomous variables, no $=0$, yes $=1$. The variable is coded 1 if respondents report that either the board of aldermen or the council or both are provided information.

† 5-point Likert scale from 1 (strongly disagree) to 5 (strongly agree). "Politicians" refer to the board of aldermen and/or the council.

The mean values indicate that both in the information and discussion phases, accountability practices more often involve the administration than the politicians: In $60 \%$ of the 
municipalities the administration is informed about goal obtainment, as compared to $47 \%$ for politicians. For running operations, the percentages are 71 and 47 respectively. As for the discussion phase, more respondents agree that enterprise goals are discussed with the administration than with the politicians. All variables are rather symmetrical and fairly spread out.

To assess the impact of the various accountability practices on perceived control, we perform an ordered logistic regression (OLR). The model estimates the odds ratio and z-scores for each independent variable. Odds ratios smaller than 1 signify a negative relationship, whereas odds ratios larger than 1 signify a positive relationship. The higher the z-score, the higher the relevance of the variable ${ }^{12}$.

Analysis of data taken from non-experimental settings such as surveys are susceptible to a number of validity threats including omitted variables, common method variance/common source bias and reverse causality (Antonakis et al. 2010). Omitted variable bias occurs if the model attributes the effect of missing variables to the estimated effects of the included variables. While sample size delimits the number of variables in the model, we included four theoretically grounded, non- or modestly correlated variables to reduce the risk of underspecifying the model. Firstly, we expect the size of the municipal administration (number of employees) to affect the capacity for oversight, and thereby the sense of control. Secondly, we included the net operating result, a much-used indicator of sound fiscal management (Borge 2005) to control for variations in managerial capacity more generally. Thirdly, we include the number of SOEs owned by the municipality in the model although expectations are ambiguous. Increasing the enterprise portfolio could either impair the sense of control because the control span widens, or increase the sense of control because the administration gains improved competence through specialisation. Fourthly, we include a measure of political fragmentation in the council. We expect councils composed by many 
small party groups to be less capable of consistent communication with the administration than councils dominated by fewer and larger parties, thus impairing the sense of control. Political fragmentation is measured by the Herfindahl index score (HIS), computed as the sum of squared shares of seats in the council for each party. HIS $=1$ (minimal fragmentation) occurs if all seats are held by one single party (Borge 2005).

Common source bias (CSB) is a salient and long-standing methodological issue in research fields relying on survey data (Doty and Glick 1998; Podsakoff et al. 2003; Meier and O'Toole Jr 2010). Originally discussed by Campbell and Fiske (1959), the essence of the CSB problem is that a non-random component of the error term introduced by the measurement method may affect the dependent and the independent variables equally much, thus inflating positive effects and conflating negative effects (Meier and O'Toole 2010). The severity of the CSB problem is however debatable. Examining 25 empirical studies published in prominent organizational research journals, Doty and Glick (1998) did find that correlations were overall, inflated. However, in most cases the bias in observed correlations was not sufficient to challenge the theoretical interpretation of the relationship (Doty and Glick 1998).

The survey method is susceptible to a number of method biases, including social desirability (answering in line with social norms), acquiescence (yea-saying), consistency motifs (attempts to maintain consistency) or implicit theories (answering based on assumed causalities) (Podsakoff et al. 2003). Extant research indicates that such biases affect some kinds of assessments more than others. Cote and Buckley (1987) found that concrete constructs that require limited judgement are less vulnerable to CSB. Similarly, Meier and O'Toole (2010) found that questions about 'how managers spend their time, questions dealing with observable behavior, (...) seem to be less affected by common source bias'. To mitigate CSB we use indicators of a factual nature as independent variables, whereas the dependent variable is evaluative. 
As for reverse causality, a distinct limitation of non-experimental, survey-based research is that causal relationships (and hence the directionality of correlations) cannot be established based on the identification of statistically significant associations alone (Kleinbaum 1998). In the present analysis, reverse causality would mean that the CO's sense of control affects the structuring of information flows between the SOEs and elected representatives/COs - not the other way around, as assumed by the model. For the reverse causality assumption to hold, the COs would have to be capable of structuring the accountability process through deliberate intervention. The fact that SOEs as legally independent entities are not subsumed under the COs chain of command, but reports directly to the mayor as the municipality's representative in the general assembly, indicates that COs are not in a position to make such interventions. Because reverse causality cannot be ruled out entirely, we carry out a series of tests reported in a separate appendix available online. The test results corroborates the analytical model's assumptions about causal ordering, suggesting that reverse causality is not a significant threat to the model's validity.

Data on the municipal economy and size of the administration was obtained from the KOSTRA register (Municipality-State Reporting), provided annually by Statistics Norway. The number of SOEs per municipality was obtained from the Norwegian Register of Business Enterprises. The Herfindahl-index for political fragmentation in the council was computed by the authors based on data from the Municipality Database. ${ }^{13}$

In October and November 2014, the authors conducted 22 interviews with elected councillors and COs in six municipalities selected as "diverse" cases (Gerring 2017), reflecting variations in number of inhabitants, size of SOE portfolio, and urbanity/rurality. All interviews were conducted by phone, recorded, and transcribed by the authors. The interviews lasted between 20 minutes and one hour. Because extant research on accountability problems associated with 
local SOEs is scarce, interviews with informants in the municipalities formed a crucial part of our overall research strategy. In the current article, observations from the qualitative study supplement the results from quantitative analysis by providing a more nuanced, in-depth understanding of accountability practices and preconditions for democratic control and oversight.

\section{Results}

The results from the ordered logistic regression analysis are presented in Table 4.

Table 4. Managers' Assessments of Municipal Control over Ownership Positions. Ordered logistic regression. $\mathrm{N}=169$

\begin{tabular}{ll|llc}
\hline & & Odds ratio & $\mathrm{z}$ & Standard \\
& & & & error \\
\hline Information & Politicians informed of goal obtainment & $2.09^{*}$ & 2.01 & 0.76 \\
& Administration informed of goal & 0.37 & -1.91 & 0.19 \\
& obtainment & & & \\
& Politicians informed of running & 1.53 & 1.20 & 0.54 \\
& operations & & & \\
& Administration informed of running & $4.98^{* *}$ & 2.88 & 2.78 \\
& operations & & & \\
\hline Discussion & Enterprise goals discussed with & $1.70^{* *}$ & 2.88 & 0.32 \\
& politicians & & & \\
& & & &
\end{tabular}




\begin{tabular}{ll|lll} 
& Enterprise goals discussed with & 0.87 & -0.70 & 0.17 \\
& administration & & & \\
\hline Consequence & Noncompliance results in board being & $1.38^{* *}$ & 2.61 & 0.17 \\
& fired & & & \\
\hline & Number of administrative employees & 1.14 & 0.62 & 0.23 \\
& Number of SOEs (ln) & 0.96 & -0.23 & 0.19 \\
& Net operating result per capita & 1.01 & 0.45 & 0.04 \\
& Political fragmentation (Herfindahl & $4.12^{*}$ & 2.10 & 2.77 \\
index) & & & \\
\hline Pseudo $R^{2}$ & & & \\
\hline
\end{tabular}

Notes: ${ }^{*} p<0.05, * * p<0.01$.

The first two variables relate to the direction of the information flow on mission-related preferences (goal obtainment). As expected, providing politicians with information on goal obtainment increases the likelihood of expressing a higher sense of control. In contrast, providing information on goal obtainment to the administration does not increase the sense of control. The third and fourth variables indicate the recipients of information on non-missionrelated preferences (running operations). As expected, providing such information to politicians does not significantly alter the perceived sense of control. Providing the administration with information on running operations, however, is associated with a more positive assessment of control. The fifth and sixth variables relate to the discussion phase, and more specifically, discussions about mission-related preferences (enterprise goals). As predicted by our model, discussing mission-related preferences with politicians is positively 
associated with the overall sense of control, whereas discussing enterprise goals with the administration does not significantly alter the likelihood of a sense of control. The seventh variable pertains to the consequences phase of SOE accountability. The results indicate that replacing SOE boards or board leaders in cases of noncompliance with the municipality's preferences increases the likelihood of a heightened sense of control.

As for the control variables, political fragmentation correlates with the sense of control, although in an unexpected direction. Contrary to what we hypothesized, the sense of control seems to increase with increasing political fragmentation. One way of interpreting this somewhat surprising finding is to draw on insights from the literature on the effects of board diversity on firm performance. For instance, Lückerath-Rovers (2013) suggested that demographically diverse boards tend to reach better decisions because a broader range of perspectives is taken into consideration. Diverse boards may stimulate the exchange of ideas, increase creativity and provide new insights (Watson, Kumar, and Michaelsen 1993, Schippers et al. 2003). Conversely, we may assume that a plurality of smaller party groups in the council stimulates political debate, hence improving political heedfulness on missionrelated preferences. The other control variables did not correlate significantly with the dependent variable.

Interviews from the six case municipalities lend support to these results. COs, SOE managers and politicians alike recommended division of labor between the administration and the politicians: While politicians should be responsible for setting the goals of the SOEs and ensure that these goals are met, the COs should be responsible for monitoring the running operations. Such division of labor was referred to as proper and even as "natural". A common thread in the informants' lines of reasoning was that politicians set goals on the citizens' behalf, so politicians should also supervise goal obtainment. However, the administration should supervise running operations because politicians lack detailed knowledge. The 
narrative about controlling SOEs was succinctly summarized by one mayor: "(As the people's representatives) politicians should ask the big questions: Why is the quality of this service so bad? Why don't people use this particular facility? Instead of drowning in details, we (the politicians) can ask: Why doesn't this SOE meet the economic goals? If you are not happy (with the answers), you can fire the board".

The norm prescribing division of labor between politicians and the administration was frequently referred to as "understanding of roles". Politicians, COs and SOE managers were highly aware of their distinct roles, and regarded proper understanding of own role as essential for retaining control. The leader of a large SOE in one of the case municipalities alleged flatly: "Unclear role understanding is the main chaos-inducing factor in public administration".

It appears from the interviews that the distinct roles attributed to politicians and administration provide legitimacy for involvement towards enterprise goals and running operations, respectively. One $\mathrm{CO}$ mentions, for example, that she cannot interfere with SOE goal obtainment, because that is the "domain of the politicians", not of the administration. Likewise, politicians recount how they act with confidence and perceived legitimacy when posing questions about goal obtainment, but also how they stay away from the detailed tasks assumed to be the responsibility of the administration. The norm prescribing division of labor seems to incur a sense of control - not necessarily because it is the most efficient way of keeping control with the SOEs, but because it is perceived as the legitimate way of keeping control. It should be noted that a number of politicians think not "being in touch" with details impairs their ability to act as ombudsman for citizens in particular need of representation. Still, even these politicians indicate that the norms prescribing division of labor takes precedence over any need to intervene on behalf of individuals or groups. 
As for the nature and contents of the mission-related preferences, these seemed to vary considerably between different SOEs, according to their core tasks. Some municipalities chose to classify their SOEs using a rough categorisation of the purpose of ownership. One municipality distinguished between three categories. Ownership of SOEs with a financial purpose was motivated by the prospect of returns on investment. Hence, mission-related preferences for these SOEs mainly related to profitability. In contrast, the municipality did not expect SOEs with a societal purpose to provide revenues. Instead, these SOEs were held accountable for their effectiveness in terms of building roads and bridges, running the cinema or providing shielded workplaces for occupational rehabilitation. A third category, of special interest in the present context, was SOEs established with a political purpose. These SOEs included a science centre, concert hall, enterprise for regional business development and centre for promoting regional movie production. According to the municipality in question, realisation of the purpose of these SOEs would be difficult without political prioritisation and engagement. Consequently, ongoing political engagement and interaction with the management of these SOEs was seen as an integral part of their mode of operation, not as 'interference'. The management of the 'financial' purpose SOEs, in contrast, were expected to operate much more autonomously in the period between general assemblies.

Clarifying the mission-related preferences for each SOE allowed the municipality to exert democratic control using the institutional structures of corporate governance; it did so, first, by formulating the statutes of each SOE at its establishment, and second, by discussing and deciding on the SOE's strategic documents in the general assembly. These documents served as a basis for holding the SOE's management accountable for mission-related preferences, while at the same time, avoiding infringement of managerial autonomy in the period between general assemblies. 


\section{Discussion}

Any talk of accountability presumes a distinction between an 'actor' to be called to account and a 'forum' that receives information, carries out discussions and ultimately decides on consequences. In terms of public service provision and task performance, given the vast range of forms in the 'administrative zoo' (Pollitt 2004) of governmental organisation, the nature and degree of the distinction between the accountor and accountee clearly varies significantly. The distinction is minimal in traditional public administration (Hood 1991; Osborne 2010), in the sense that both parties to the accountability relationship are embedded in the same comprehensive, highly formalised and hierarchically organised system - hence the label 'integrated' accountability. In contrast, the corporate form provides a high degree of managerial autonomy by design, while minimising 'interference' by the owners. The implication is that the distinction between the actor and forum becomes much more marked. By conceptualising 'corporate governance' as the private-sector counterpart of the 'integrated' model of accountability in the public sector, we sought to highlight the basic dilemma that arises from attempting to combine the two models: How can adequate levels of control be ensured, given a much higher degree of managerial autonomy?

Responding to this dilemma, we developed a model for structuring the accountability relation between SOEs and their public owners, based on extant research and our conceptual discussion. The model prescribes a distinction between the roles of top managers and elected representatives as 'forums' for accountability (Figure 2). Our model emphasises a strong and direct role for politicians on matters related to SOE goals. In terms of the SOE's running operations, however, the model prescribes an indirect relationship between elected politicians and the SOE. Introducing top public managers as primary recipients of information on the running operations of the SOE has the dual benefit of increasing the governmental owner's capacity for oversight, and at the same time, insulating the management of the SOE from 
undue interference in day-to-day decisions. Top managers would be responsible for keeping politicians informed about running operations, especially in cases where there is reason to fear wrongdoing or breaches of legal standards. Because public managers cannot legally intervene directly in the running operations of the SOE, the autonomy of SOE management is preserved. Pursuant to corporate law, the 'consequences' phase is a distinctly political domain in any case. However, because the top manager would be the primary recipient of information on running operations, political intervention due to non-mission-related preferences would only occur in the event of malfeasance.

The purpose of the empirical analysis was to gauge the relevance of our model. We assumed that accountability practices in line with the prescriptions of the model would be associated with a heightened sense of control over the SOEs. Overall, the analysis results supported our assumptions. The informants tended to evaluate their municipality's degree of control more positively in cases where actual information flows, discussions and the consequences phase of the accountability process were structured as prescribed in the model. The ideal situation involves directing information and discussions on goal-related issues to politicians and leaving the administration out. In contrast, the administration is clearly seen as the correct recipient for information about running operations. Although these results seem encouraging, the model raises a number of issues that must be addressed before a conclusion about its utility can be made.

A basic premise of the model is role differentiation between elected politicians and public managers. On a general level, this feature of the model carries connotations of a 'frontier' between politics and management (Pollitt and Bouckaert 2011). The practical relevance of such a frontier is certainly debatable. Recent management reforms may have brought about an invasion of the political domain by administrators, and conversely, invasion of the administrative domain by politicians (p. 161). Furthermore, extant research indicates that the 
politics-management divide tends to be blurred in 'the apex' of local government organisation, in the sense that there is limited role distinction between the mayor and $\mathrm{CO}$ in practice (Mouritzen and Svara 2002). In light of this, the model's reliance on differentiation between mission related and non-mission related fields of responsibility clearly requires further consideration. A first step is to note that the model does not imply that top public managers should be accountable for actions taken by the SOE management. With reference to current debate in the United Kingdom on civil servants' accountability, we do not propose to distinguish between 'accountability' and 'responsibility' in such a way that elected politicians can avoid responsibility by pointing at top public managers while retaining formal accountability (HoL 2012). Placing the blame on the top public managers for actions taken by SOE management would clearly be untenable: SOEs are independent legal entities, and as such, not parts of the administrative hierarchy. However, the model underscores that top public managers are responsible for staying closely informed about the SOEs and for keeping politicians in the loop about any relevant developments. In other words, while top public managers cannot be accountable for SOE misconduct, they can be held responsible for not passing on relevant information to their elected principals.

Following this, any problems of isolating non-mission-related preferences from missionrelated preferences, and furthermore, deciding on what specific information political principals should receive, would need to be sorted out by top public managers. Indeed, the model suggests that sound discretion in terms of deciding on the kinds of information to pass on to political principals would be a key qualification of top public managers working for governments that own SOEs. The implication is that, while the managerial role of top public managers constricts by moving tasks and services outside of the governmental hierarchy, the controlling role of top public managers expands. 
The 'consequences' phase of the accountability relationship between the SOE and its municipal owners resides with elected politicians, regardless of what kind of preferences mission-related or non-mission-related - are at stake. In the public eye, cases involving severe managerial defaults or downright malfeasance, for instance, in the form of corruption or embezzlement, would probably figure most prominently among the situations where SOE management is called to account. Uncovering such cases tends to occasion considerable media attention, as does the outcome of the consequences phase, for instance, the replacement of the board or even levelling of criminal charges. While obviously a crucial aspect to the role of elected politicians in holding SOEs accountable, there is also a less dramatic, and at times, strangely elusive element to the role of the municipality's political principals as a forum, specifically, overseeing the SOE's fulfilment of its purpose and considering the interchange between the SOE's strategy and other politically relevant factors. This dimension of accountability relates directly to the municipal owner's mission-related preferences, and as such, it is at the heart of democratic governance. Yet, the very idea of mixing business and politics is often seen as an abomination, not least in management circles. Possibly, ensuring accountability over non-mission-related preferences is deemed as more understandable and straightforward than holding SOEs accountable for mission-related preferences. Few, if any, would voice principled objections against municipal owners replacing the board of an SOE following an audit uncovering malfeasance or mismanagement. However, any talk about 'political' considerations in the context of corporate strategy runs the risk of immediately being branded as inappropriate or inadmissible. Clearly, for the model proposed above to be workable, there is a need for clarifying the legitimate and proper place for politics in the context of SOEs.

One approach to answering this question is to note that, ultimately, the general purpose of all tasks and activities carried out in the public sector is to implement a political decision. 
Establishing an SOE or deciding to buy into in a pre-existing SOE is no exception. After all, many tasks divested to the SOEs included in our study were carried out administratively in other municipalities. A key to finding the proper place for politics in the context of SOEs may be clarifying the purpose of owning each SOE in particular.

\section{Conclusions}

Our point of departure was that political control over SOEs requires reconciliation of two disparate systems for control and accountability - the traditional "integrated" system of democratic government, and private sector "corporate governance". The article's theoretical contribution is the development of a model that combines these very distinct accountability systems, thereby demonstrating how the principles of democratic political control can be maintained without jeopardizing managerial autonomy. The qualitative data from our study indicates that politicians, COs and SOE managers in Norwegian local governments have developed certain norms, principles and procedures that enable them to navigate the murky waters of SOE governance; to retain political control without infringing on the prerogatives of SOE management. The conclusion from the qualitative analysis is that these practice-based understandings seem highly congruent with the theoretical model. While these findings from a limited sample of informants offer some reassurance as regards the relevance of the theoretical model, the survey to all Norwegian local governments put the qualitative findings on a more solid footing, largely supporting the findings from the qualitative studies. According to the perceptions of municipal COs, a precondition for effective control is that SOEs are accountable to elected politicians as regards goal formulation and goal obtainment, furthermore that politicians ensure that there are consequences if set goals are not met. 
Concurrently, top managers should be responsible for overseeing running operations of the SOEs, and report to their elected superiors to the extent that is required.

As noted, empirical studies on accountability practices towards SOEs are still scarce. Further empirical studies are needed in order to test the relevance of the model in other institutional settings and on other levels of government. While conceptions about key tenants of this private-sector system of accountability and control seems to converge, one would expect significant variations between countries and business sectors. Conversely, there is no globally shared conception of parliamentary accountability either. Notably, we would like to see studies that emphasize the political goals that SOEs are set up to achieve, and the mechanisms that are used for ensuring democratic accountability while avoiding undue interference in managerial autonomy.

\section{Acknowledgements}

The authors would like to thank Tom Christensen, as well as two anonymous reviewers, for their thoughtful feedback on earlier drafts of this manuscript.

\section{Data Availability Statement}

Replication materials are available in the Journal of Public Policy Dataverse at https://doi.org/10.7910/DVN/TMO87V 


\section{References}

Aars J. and Ringkjøb H.-E. (2011) Local Democracy Ltd: The political control of local government enterprises in Norway. Public Management Review 13: 825-844.

Aarsæther N. and Vabo S. I. (2002) Fristilt og velstyrt? Fokus på kommune-Norge. Oslo: Samlaget.

Allison G. (1982) Public and Private Management: Are They Fundamentally Alike in All Unimportant Respects? In Lane F. S. (ed) Current Issues in Public Administration. New York: St Martin's Press, 13-33.

André R. (2010) Assessing the Accountability of Government-Sponsored Enterprises and Quangos. Journal of Business Ethics 97: 271-289.

Antonakis J., Bendahan S., Jacquart P., and Lalive R. (2010) On making causal claims: A review and recommendations. The Leadership Quarterly 21: 1086-1120.

Aucoin P. (1990) Administrative Reform in Public Management: Paradigms, Principles, Paradoxes and Pendulums. Governance 3: 115-137.

Barberis P. (1998) The New Public Management And A New Accountability. Public Administration 76: 451-470.

Barker A. (1982) Quangos in Britain: Government and the Networks of Public PolicyMaking. London: MacMillian.

Berle A. A. and Means G. C. (1933) The modern corporation and private property, New York: Macmillan.

Bjørnsen H.M., Klausen J.E., and Winsvold M. (2015) Kommunale selskap og folkevalgt styring gjennom kommunalt eierskap, NIBR-report 2015:1. Oslo: NIBR (Norwegian Institute for Urban and Regional Research). 
Blair M. M. (1995) Ownership and control : rethinking corporate governance for the twentyfirst century, Washington, D.C: Brookings Institution.

Bognetti G. and Obermann G. (2012) Local Public Services in European Countries: Main Results of a Research Project by Ciriec International. Annals of Public and Cooperative Economics 83: 485-503.

Borge L.-E. (2005) Strong politicians, small deficits: evidence from Norwegian local governments. European Journal of Political Economy 21: 325-344.

Bovens M. (2005) Public accountability. In Ferlie E., Lynn Jr. L.E., and Pollitt C. (eds) The Oxford handbook of public management. Oxford, UK: Oxford University Press., 182208).

Bovens M. (2007) Analysing and Assessing Accountability: A Conceptual Framework. European Law Journal 13: 447-468.

Bovens M., Goodin R. E., and Schillemans T. (2014) The Oxford Handbook of Public Accountability. 1 ed. Oxford: Oxford University Press.

Bovens M. A. P., t ${ }^{\prime}$ Hart P., and Schillemans T. (2008) Does public accountability work? An assesment tool. Public Administration 86: 225-242.

Brandsma G. J. and Schillemans T. (2013) The Accountability Cube: Measuring Accountability. Journal of Public Administration Research and Theory 23: 953-975.

Brennan N. and Solomon J. (2008) Corporate governance, accountability and mechanisms of accountability: an overview. Accounting, Auditing \& Accountability Journal 21: 885906.

Bruton G. D., Peng M. W., Ahlstrom D., Stan C., and Xu K. (2015) State-owned enterprises around the world as hybrid organizations. Academy of Management Perspectives 29: 92-114. 
Caiden G. E. (1994) Administrative Reform-American Style (Book Review). Public Administration Review 54: 123-128.

Campbell D. T., Fiske D. W., and Helson H. (1959) Convergent and discriminant validation by the multitrait-multimethod matrix. Psychological Bulletin 56: 81-105.

Christensen T. and Lægreid P. (2001) New public management : the transformation of ideas and practice, Aldershot: Ashgate.

Christensen T. and Lægreid P. (2006) Autonomy and regulation : coping with agencies in the modern state, Cheltenham: Edward Elgar.

Christensen T., Lægreid P., Peters B. G., and Bouckaert G. (2004) Governmental autonomisation and control: the Norwegian way. Public Administration and Development 24: 129-135.

Citroni G., Lippi A., and Profeti S. (2013) Remapping the State: Inter-Municipal Cooperation through Corporatisation and Public-Private Governance Structures. Local Government Studies 39: 208-234.

Cote J. A. and Buckley M. R. (1987) Estimating Trait, Method, and Error Variance: Generalizing across 70 Construct Validation Studies. Journal of Marketing Research 24: $315-318$.

Denters B. and Rose L. E. (2005) Towards Local Governance? In Denters B. and Rose L. E. (eds) Comparing Local Governance. Trends and Developments. Basingstoke: Palgrave, 246-262.

Doty D. H. and Glick W. H. (1998) Common Methods Bias: Does Common Methods Variance Really Bias Results? Organizational Research Methods 1: 374-406.

Esping-Andersen G. (1990) The three worlds of welfare capitalism, Cambridge: Polity Press. Fuller D. and Roffey B. (1993) Improving Public Sector Accountability and Strategic Decision-Making. Australian Journal of Public Administration 52: 149-163. 
Gjertsen A. and Martiniussen K. (2006) Styring og kontroll av kommunale selskaper og foretak. NF-rapport (18). Bødo: Nordlandsforskning.

Gray A. and Jenkins B. (1995) From Public Administration to Public Management: Reassessing a Revolution? Public Administration 73: 75-99.

Grossi G., Papenfuß U., and Tremblay M.-S. (2015) Corporate governance and accountability of state-owned enterprises: Relevance for science and society and interdisciplinary research perspectives. International Journal of Public Sector Management 28: 274285.

Hart O. (1995) Corporate Governance: Some Theory and Implications. The Economic Journal 105: 678-689.

Hodge G. and Coghill K. (2007) Accountability in the privatized state. Governance 20: 675702.

HoL (2012) The accountability of civil servants. 6th Report of Session 2012-13. House of Lords. Select committee on the Constitution. London: The Stationery Office Limited. Hood C. (1991) A public management for all seasons? Public Administration 69: 3-19.

Hood C. (2002) The Risk Game and the Blame Game. Government and Opposition 37: 1537.

Hood C. (2011) The blame game : spin, bureaucracy, and self-preservation in government, Princeton, New Jersey: Princeton University Press.

Hughes O. (1992) Public Management or Public Administration? Australian Journal of Public Administration 51: 286-296.

Johnson N. (1982) Accountability, control and complexity. In Barker A. (ed) Quangos in Britain. Government and the Networks of Policy-Making. London: The Mackmillian Press ltd., 206-218. 
Jones G. W. (1992) The search for local accountability. In Leach S. (ed) Strengthening local government in the 1990s. London: Longman, 49-78.

Kettl D. F. (1997) The Global Revolution in Public Management: Driving Themes, Missing Links. Journal of Policy Analysis and Management 16: 446-462.

Kleinbaum D. G. (1998) Applied regression analysis and other multivariable methods, Pacific Grove, Calif: Duxbury Press.

Koppell J. G. S. (2003) The politics of quasi-government : hybrid organizations and the dynamics of bureaucratic control, Cambridge: Cambridge University Press.

Kuhlmann S. (2008) Reforming local public services: Trends and effects in Germany and France. Public Management Review 10: 573-596.

Lewis N. and Longley D. (1996) Ministerial responsibility: the next steps. Public Law (autumn): 490-507.

Luke B. (2010) Examining Accountability Dimensions in State-Owned Enterprises. Financial Accountability \& Management 26: 134-162.

Meier K. J. and O'Toole Jr LJ. (2010) Organizational Performance: Measurement Theory and an Application: Or, Common Source Bias, the Achilles Heel of Public Management Research. 106th Annual Meeting of the American Political Science Association (APSA) 2010.

Mouritzen P. E. and Svara J. H. (2002) Leadership at the apex : politicians and administrators in Western local governments, Pittsburgh, Pa: University of Pittsburgh Press.

Mulgan R. (1997) Contracting Out and Accountability. Australian Journal of Public Administration 56: 106-116.

Mulgan R. (2014) Accountability Deficits. In Bovens M., Goodin R. E., and Schillemans T. (eds) Oxford Handbook of Public Accountability Oxford: Oxford University Press. 
OECD (2015a) G20/OECD Principles of Corporate Governance, Paris: OECD Publishing.

OECD (2015b) Government at a Glance 2015. OECD Publishing.

OECD (2015c) OECD Guidelines on Corporate Governance of State-Owned Enterprises, 2015 Edition, Paris: OECD Publishing.

Olsen T. H., Solstad E., and Torsteinsen H. (2017) The meaning of institutional logics for performance assessment in boards of municipal companies. Public Money \& Management 37: 393-400.

Osborne S. P. (2010) The new public governance? : emerging perspectives on the theory and practice of public governance. New York: Routledge.

Painter M. (1988) Editorial Public Management: Fad or Fallacy? Australian Journal of Public Administration 47: 1-3.

Parker L. D. and Gould G. (1999) Changing public sector accountability: Critiquing new directions. Accounting Forum 23: 109-135.

Podsakoff P. M., Mackenzie S. B., Lee J.-Y., Podsakoff N. P., and Zedeck S. (2003) Common Method Biases in Behavioral Research: A Critical Review of the Literature and Recommended Remedies. Journal of Applied Psychology 88: 879-903.

Pollitt C. (2004) Agencies : how governments do things through semi-autonomous organizations, Basingstoke: Palgrave Macmillan.

Pollitt C., Bathgate K., Caulfield J., Smullen A., and Talbot C. (2001) Agency fever? Analysis of an international policy fashion. Journal of Comparative Policy Analysis: Research and Practice 3: 271-290.

Pollitt C. and Bouckaert G. (2011) Public management reform: a comparative analysis : new public management, governance, and the neo-Weberian state, Oxford: Oxford University Press. 
Pollitt C. and Talbot C. (2004) Unbundled government : a critical analysis of the global trend to agencies, quangos and contractualisation, London: Routledge.

Schillemans T. (2011) Does Horizontal Accountability Work? Administration \& Society 43: $387-416$.

Schippers M. C., Den Hartog D. N., Koopman P. L., and Wienk J. A. (2003) Diversity and team outcomes: the moderating effects of outcome interdependence and group longevity and the mediating effect of reflexivity. Journal of Organizational Behavior 24: $779-802$.

Sellers J. M. and Lidström A. (2007) Decentralization, Local Government, and the Welfare State. Governance 20: 609-632.

Teles F. (2015) Local Governance and Intermunicipal Cooperation, Basingstoke: Palgrave Macmillan UK.

Thynne I. (2011) Ownership as an instrument of policy and understanding in the public sphere: trends and research agenda. Policy Studies 32: 183-197.

Tricker B. (1995) Corporate Governance - a subject whose time has come. Corporate Governance: An International Review 3: 187-188.

Verhoest K., Roness P. G., Verschuere B., Rubecksen K., and MacCarthaigh M. (2010) Autonomy and Control of State Agencies : Comparing States and Agencies, Basingstoke: Palgrave Macmillan.

Verhoest K., Van Thiel S., Bouckaert G., and Lægreid P. (2012) Government Agencies: Practices and Lessons from 30 Countries. Basingstoke: Palgrave, 369-371.

Warner M. and Hebdon R. (2001) Local Government Restructuring: Privatization and Its Alternatives. Journal of Policy Analysis and Management 20: 315-336. 
Watson W. E., Kumar K., and Michaelsen L. (1993) Cultural diversity's impact on interaction process and performance : comparing homogeneous and diverse task groups.

Willems T. and Van Dooren W. (2012) Coming to Terms with Accountability: Combining multiple forums and functions. Public Management Review 14: 1-26.

Wollmann H., Koprić I. and Marcou G. (2016) Public and Social Services in Europe. From Public and Municipal to Private Sector Provision. London: Palgrave Macmillan UK.

Zatti A. (2012) New Organizational Models in European Local Public Transport: From Myth to Reality. Annals of Public and Cooperative Economics 83: 533-559. 
Figure 1: Model of Corporate Governance. Adopted from Tricker (1995).

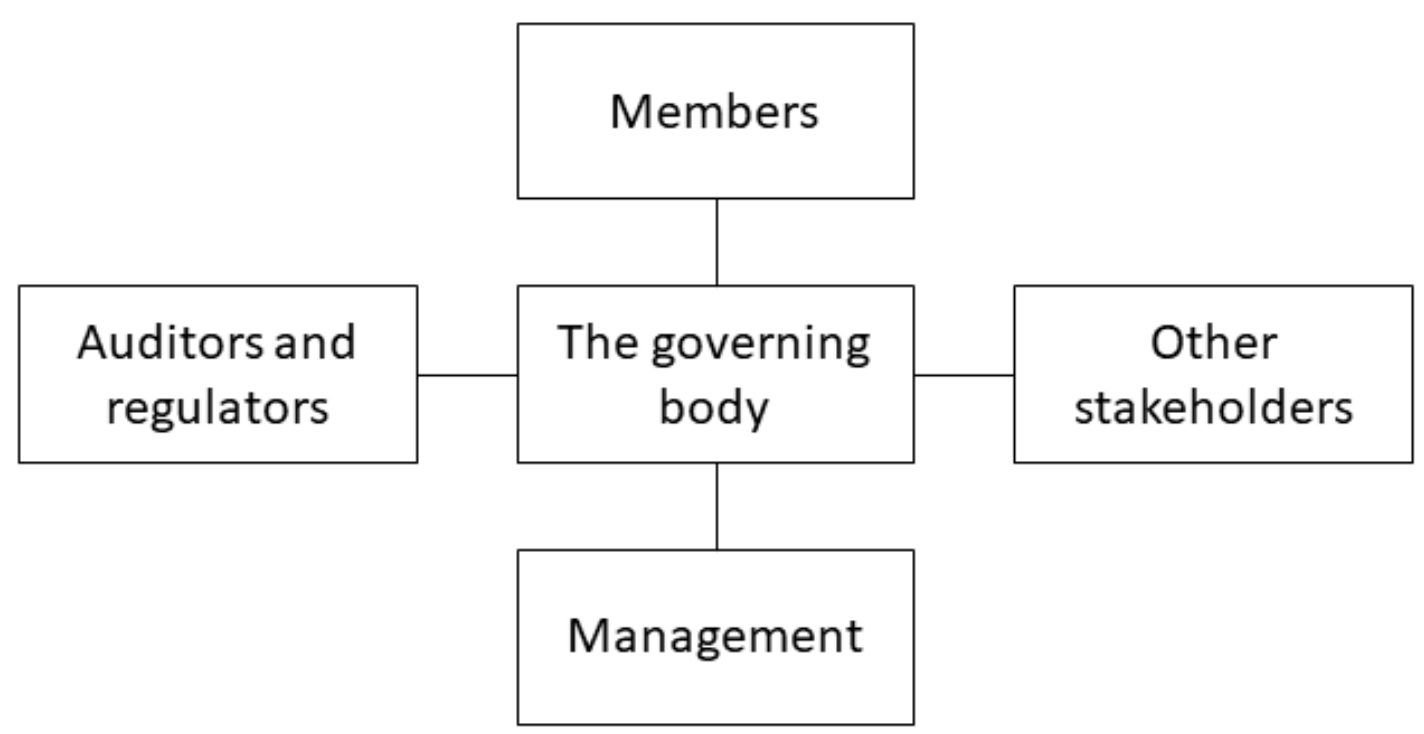


Figure 2: Model for Structuring Accountability on Mission-Related (1) and Non-MissionRelated (2) Preferences.

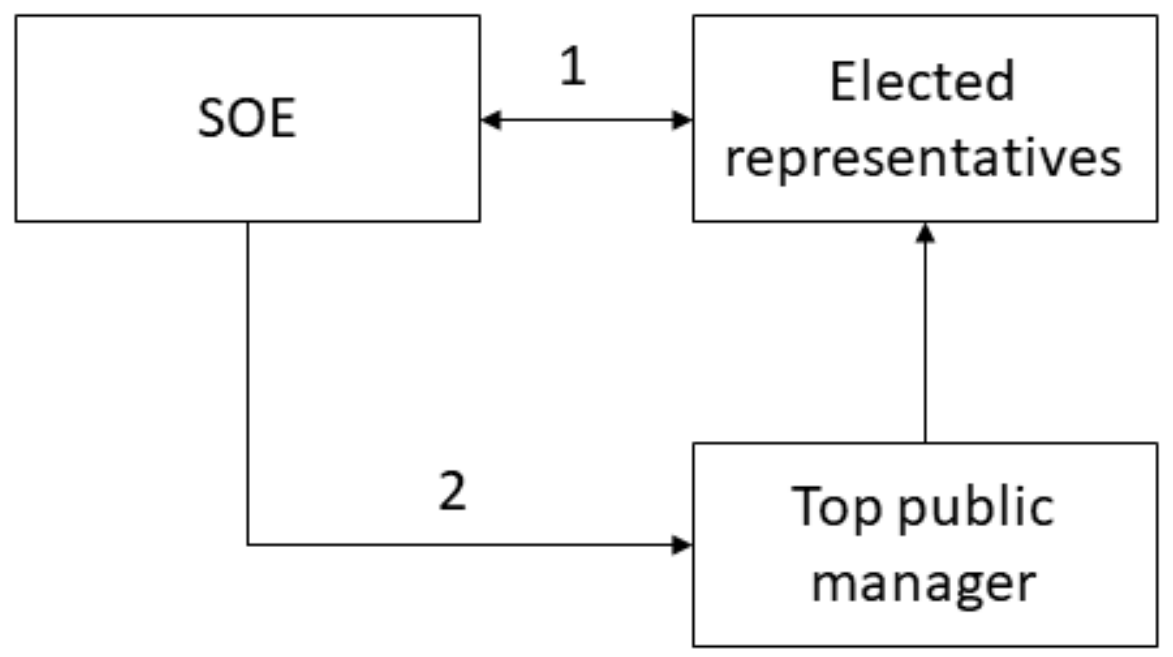


Table 1: Norwegian Local State-Owned Enterprises by Branch of Industry (2014) †. Source:

Register of Business Enterprises/Brønnфysund Register Centre. $N=2020$

Industry

Electricity, gas, steam and hot water supply

Real estate management

Work training and adapted employment

Business development, telecommunications and technical service

Culture, education, leisure and tourism

Water, sewage and renovation

Transport

Building and construction, planning and technical services

Kindergartens, education, health-and care services, $A S$

Public administration, general

Fire protection

Other production and service provision

SUM
Percentage

$20 \%$

$18 \%$

$14 \%$

$9 \%$

$8 \%$

$8 \%$

$7 \%$

$6 \%$

$3 \%$

$3 \%$

$2 \%$

$2 \%$

\footnotetext{
$\uparrow$ Limited corporations (Ltd.) and Inter-Municipal Companies (IMC). Each Ltd or IMC may comprise one or several units.
} 
Table 2. "The municipality exerts adequate control over its ownership interests".

Distribution on dependent variable. $N=171$. Source: Survey

\begin{tabular}{lcc}
\hline & Percent & $\mathrm{N}$ \\
\hline 1 (Strongly disagree) & $9 \%$ & 16 \\
2 & $19 \%$ & 32 \\
3 & $32 \%$ & 55 \\
4 & $36 \%$ & 61 \\
5 (Strongly agree) & $4 \%$ & 7 \\
\hline Total & $100 \%$ & 171 \\
\hline Mean & 3.06 & \\
\hline
\end{tabular}


Table 3 Independent variables. Mean values, standard deviation and skewness. $N=169$.

Source: Survey

\begin{tabular}{|c|c|c|c|c|c|c|}
\hline & & Min & Max & Mean & $\begin{array}{l}\text { Std. } \\
\text { Dev. }\end{array}$ & $\begin{array}{l}\text { Skew- } \\
\text { ness }\end{array}$ \\
\hline \multirow[t]{4}{*}{ Information $\dagger$} & $\begin{array}{l}\text { The politicians are provided } \\
\text { information about the goal } \\
\text { obtainment of the enterprise(s) }\end{array}$ & 0 & 1 & 0.47 & 0.50 & 0.11 \\
\hline & $\begin{array}{l}\text { The administration is provided } \\
\text { information about the goal } \\
\text { obtainment of the enterprise(s) }\end{array}$ & 0 & 1 & 0.60 & 0.49 & -0.43 \\
\hline & $\begin{array}{l}\text { The politicians are provided } \\
\text { information about the running } \\
\text { operations of the enterprise(s) }\end{array}$ & 0 & 1 & 0.47 & 0.50 & 0.11 \\
\hline & $\begin{array}{l}\text { The administration is provided } \\
\text { information about the running } \\
\text { operations of the enterprise(s) }\end{array}$ & 0 & 1 & 0.71 & 0.45 & -0.94 \\
\hline \multirow[t]{2}{*}{ Discussion $\dagger \dagger$} & $\begin{array}{l}\text { Enterprise goals are discussed } \\
\text { with politicians }\end{array}$ & 1 & 5 & 3.00 & 1.06 & 0.04 \\
\hline & $\begin{array}{l}\text { Enterprise goals are discussed } \\
\text { with administration }\end{array}$ & 1 & 5 & 3.50 & 1.22 & -0.48 \\
\hline Consequence $\dagger \dagger$ & $\begin{array}{l}\text { The municipality fire the board } \\
\text { leader or the board in case of } \\
\text { noncompliance. }\end{array}$ & 1 & 5 & 2.80 & 1.33 & 0.06 \\
\hline \multirow[t]{4}{*}{ Control } & $\begin{array}{l}\text { Number of administrative } \\
\text { employees (ln) }\end{array}$ & 3.5 & 10.4 & 6.3 & 1.06 & 0.53 \\
\hline & Number of SOEs $(\ln )$ & 0 & 4.72 & 1.57 & 1.05 & 0.39 \\
\hline & Net operating result per capita & -4.4 & 43.7 & 2.45 & 4.28 & 5.99 \\
\hline & $\begin{array}{l}\text { Political fragmentation, } \\
\text { Herfindahl index (ln) }\end{array}$ & 0.14 & 0.70 & 0.27 & 0.08 & 1.82 \\
\hline
\end{tabular}

$\uparrow$ Dichotomous variables, no $=0$, yes $=1$. The variable is coded 1 if respondents report that either the board of aldermen or the council or both are provided information.

$\dagger \dagger 5$-point Likert scale from 1 (strongly disagree) to 5 (strongly agree). "Politicians" refer to the board of aldermen and/or the council. 
Table 4. Managers' Assessments of Municipal Control over Ownership Positions. Ordered logistic regression. $N=169$. Source: Survey

\begin{tabular}{|c|c|c|c|c|}
\hline & & Odds ratio & $\mathrm{z}$ & $\begin{array}{l}\text { Standard } \\
\text { error }\end{array}$ \\
\hline \multirow[t]{6}{*}{ Information } & Politicians informed of goal obtainment & $2.09 *$ & 2.01 & 0.76 \\
\hline & $\begin{array}{l}\text { Administration informed of goal } \\
\text { obtainment }\end{array}$ & 0.37 & -1.91 & 0.19 \\
\hline & Politicians informed of running & 1.53 & 1.20 & 0.54 \\
\hline & operations & & & \\
\hline & Administration informed of running & $4.98 * *$ & 2.88 & 2.78 \\
\hline & operations & & & \\
\hline \multirow[t]{2}{*}{ Discussion } & $\begin{array}{l}\text { Enterprise goals discussed with } \\
\text { politicians }\end{array}$ & $1.70^{* * *}$ & 2.88 & 0.32 \\
\hline & $\begin{array}{l}\text { Enterprise goals discussed with } \\
\text { administration }\end{array}$ & 0.87 & -0.70 & 0.17 \\
\hline \multirow[t]{6}{*}{ Consequence } & $\begin{array}{l}\text { Noncompliance results in board being } \\
\text { fired }\end{array}$ & $1.38 * *$ & 2.61 & 0.17 \\
\hline & Number of administrative employees & 1.14 & 0.62 & 0.23 \\
\hline & Number of SOEs (ln) & 0.96 & -0.23 & 0.19 \\
\hline & Net operating result per capita & 1.01 & 0.45 & 0.04 \\
\hline & $\begin{array}{l}\text { Political fragmentation (Herfindahl } \\
\text { index) }\end{array}$ & $4.12 *$ & 2.10 & 2.77 \\
\hline & Pseudo $R^{2}$ & 0.102 & & \\
\hline
\end{tabular}

Notes:, ${ }^{*} p<0.05,{ }^{* *} p<0.01$. 


\footnotetext{
${ }^{1}$ The peer-reviewed journal Corporate Governance includes the following in its mission statement: 'Our ultimate goal is a rigorous and relevant global theory of corporate governance'.

${ }^{2}$ In Norway, all listed companies are legally required to provide an account of how they comply with principles of corporate governance (Accounting Act of 1988, § 3-3b).

${ }^{3}$ The term 'state-owned enterprise' refers to enterprises owned by governments at the national, regional and local levels (OECD 2015c; Grossi et al. 2015).

${ }^{4}$ A broader definition of accountability would include such diverse meanings as transparency, equity, democracy, efficiency, responsiveness, responsibility and integrity (Bovens 2007). The conceptual literature on public accountability has been reviewed elsewhere (Willems and Van Dooren 2012; Bovens et al. 2014), and does not need to be rehashed here.

${ }^{5}$ A key observation in the accountability literature is that these hierarchically ordered accountability relationships are supplemented with various horizontal relationships, in which the forum is not hierarchically superior to the agent (Bovens 2005; Bovens et al. 2008). Horizontal accountability relationships can involve, for instance, the media, clients or evaluators, depending on the context.

${ }^{6}$ See Brennan and Solomon (2008) for a review of research on corporate governance using an agency theory approach.

${ }^{7}$ With reference to Barker (1982).

${ }^{8}$ In André's (2010) terminology, SOEs belong to the wider category of 'grey sector organisations' (GSOs).

${ }^{9}$ Norway is a unitary state with two levels of subnational government. At the time of the study, there were 430 primary municipalities and 18 county municipalities. A highly decentralised social democratic welfare state (Esping-Andersen 1990; Sellers and Lidström 2007), Norway's local government sector consumes $33.2 \%$ of the general government expenditures (OECD 2015b). The principle of general competence applies - all local governments are obliged by law to provide the same set of services. Most Norwegian municipalities are organized according to the aldermen principle, in which the political executive, formannsskapet, is composed of representatives of all or most political parties in the municipal council. The chief officer is hired by the municipal council, and this individual is accountable to the council for the entire municipal administration.

${ }^{10}$ Variations in the response rate according to the number of SOEs owned by the municipality could induce bias in the sample. Therefore, the number of SOEs owned by the municipality is included as a control variable (see p. 16).

${ }^{11}$ See appendix for question formulations.

12 To detect collinearity of the regressors with the constant, we have calculated the variance inflation factors (VIF) and tolerances for each of the independent variables. The results do not indicate a multicollinearity problem. The VIF table is presented in the appendix.

${ }^{13}$ Part of the data used for this article was taken from the Municipality Database of NSD - Norwegian Center for Scientific Data ltd. NSD is not responsible for the analysis of the data or interpretations made here.
} 


\section{APPENDIX}

Survey questions and construction of variables

\section{Dependent variable}

(Q38) On a scale from 1 (strongly disagree) to 5 (strongly agree), to what extent would you say you agree to the following statement:

"The municipality exerts adequate control over its ownership interests"

\section{Independent variables, information}

(Q29_1) Who get information on the SOEs goal obtainment?

1. The board of aldermen 2: The municipal council 3: The municipal administration.

(Q29_2)“Who get information on the SOEs running operations?

1. The board of aldermen 2: The municipal council 3: The municipal administration.

The variables used in the OLR model "The Politicians are provided information about the goal obtainment of enterprise(s)" and "The politicians are provided information about the running operations of the enterprise(s)" are coded 0 when neither the board of aldermen nor the municipal council is informed and 1 when either or both are informed.

\section{Independent variables, discussion}

(Q6) On a scale from 1 (strongly disagree) to 5 (strongly agree), to what extent would you say you agree to the following statement:

(Q6_1) "The goals and performance requirements of the SOEs are discussed in the board of aldermen"

(Q6_2) "The goals and performance requirements of the SOEs are discussed in the municipal council"

(Q6_3) "The goals and performance requirements of the SOEs are discussed in the municipal administration"

To compute the variable "Enterprise goals are discussed with politicians" responses to Q6_1 and Q6_2 were summarized and divided by two.

\section{Independent variable, consequences}

(Q47) On a scale from 1 (strongly disagree) to 5 (strongly agree), to what extent would you say you agree to the following statement:

"The municipality fire the board leader or the board in case of noncompliance" 
Variance inflation factors (VIFs) for independent variables $*$ in model. $N=169$.

\begin{tabular}{l|l}
\hline Variable & $\begin{array}{l}\text { Variance inflation factors } \\
\text { (VIFs) }\end{array}$ \\
\hline Administration informed of goal obtainment & 3.08 \\
Administration informed of running operations & 2.88 \\
Politicians informed of goal obtainment & 2.39 \\
Politicians informed of running operations & 2.20 \\
Enterprise goals discussed with administration & 1.78 \\
Enterprise goals discussed with politicians & 1.63 \\
Number of SOEs & 1.22 \\
Noncompliance results in board being fired & 1.22 \\
Number of administrative employees & 1.17 \\
Political fragmentation (Herfindahl index) & 1.17 \\
Net operating profit per capita & 1.06 \\
\hline Mean VIF & 1.80 \\
\hline
\end{tabular}

* VIF scores computed on untransformed variables 